NBER WORKING PAPER SERIES

\title{
EVOLUTION OF MODERN BUSINESS CYCLE MODELS: ACCOUNTING FOR THE GREAT RECESSION
}

\author{
Patrick J. Kehoe \\ Virgiliu Midrigan \\ Elena Pastorino \\ Working Paper 24741 \\ http://www.nber.org/papers/w24741 \\ NATIONAL BUREAU OF ECONOMIC RESEARCH \\ 1050 Massachusetts Avenue \\ Cambridge, MA 02138 \\ June 2018
}

We thank Adrien Auclert, Mark Gertler, Robert Hall, Gordon Hanson, Robert Lucas, Ellen McGrattan, Juan Pablo Nicolini, John Taylor, and Timothy Taylor for their comments, and are especially thankful to John Cochrane for his detailed feedback. The views expressed herein are those of the authors and not necessarily those of the Federal Reserve Bank of Minneapolis, the Federal Reserve System, or the National Bureau of Economic Research.

NBER working papers are circulated for discussion and comment purposes. They have not been peer-reviewed or been subject to the review by the NBER Board of Directors that accompanies official NBER publications.

(C) 2018 by Patrick J. Kehoe, Virgiliu Midrigan, and Elena Pastorino. All rights reserved. Short sections of text, not to exceed two paragraphs, may be quoted without explicit permission provided that full credit, including $(\odot$ notice, is given to the source. 
Evolution of Modern Business Cycle Models: Accounting for the Great Recession

Patrick J. Kehoe, Virgiliu Midrigan, and Elena Pastorino

NBER Working Paper No. 24741

June 2018

JEL No. E13,E32,E52,E61,E62

\section{ABSTRACT}

Modern business cycle theory focuses on the study of dynamic stochastic general equilibrium models that generate aggregate fluctuations similar to those experienced by actual economies. We discuss how this theory has evolved from its roots in the early real business cycle models of the late 1970s through the turmoil of the Great Recession four decades later. We document the strikingly different pattern of comovements of macro aggregates during the Great Recession compared to other postwar recessions, especially the 1982 recession. We then show how two versions of the latest generation of real business cycle models can account, respectively, for the aggregate and the cross-regional fluctuations observed in the Great Recession in the United States.

Patrick J. Kehoe

Department of Economics

Stanford University

579 Serra Mall

Stanford, CA 94305

and NBER

patrickjameskehoe@gmail.com

Virgiliu Midrigan

Department of Economics

New York University

19 W. 4th St.

New York, NY 10012

and NBER

virgiliu.midrigan@nyu.edu
Elena Pastorino

Stanford University

Hoover Institution and Economics Department

579 Serra mall

94305

Stanford University

Palo Alto, CA 94305

and the Federal Reserve Bank of Minneapolis

epastori@stanford.edu 
Modern business cycle theory focuses on the study of dynamic stochastic general equilibrium models that generate aggregate fluctuations similar to those experienced by actual economies. We discuss how this theory has evolved across three generations, from its roots in the early real business cycle models of the late 1970s through the turmoil of the Great Recession four decades later.

The first generation of these modern business cycle models were real business cycle models. They primarily explored whether a small number of shocks, often one or two, could generate fluctuations similar to those observed in aggregate variables such as output, consumption, investment, and hours. These simple models disciplined their key parameters with micro evidence and were remarkably successful in matching these aggregate variables.

Over time, as the theory evolved and computational possibilities expanded, a second generation of these models appeared. These models incorporated frictions such as sticky prices and wages, and were primarily developed to be used in central banks for short-term forecasting purposes and for performing counterfactual policy experiments. Due to the focus on forecasting, the main emphasis in choosing the parameters of these models was on their ability to match the behavior of, say, 10 to 12 aggregate variables rather than on carefully matching them up with micro evidence. Although these models were called New Keynesian, they had little to do with traditional Keynesian models. Rather, they were simply real business cycle models augmented with sticky prices and wages. Indeed, a canonical real business cycle model augmented with money and flexible prices—so that monetary policy can be meaningfully discussed-has essentially the same implications for the importance of various shocks for business cycles and nearly identical implications for optimal monetary and fiscal policy as these New Keynesian models do.

During the last decade or so, macroeconomists working on the next generation of models have benefited from the development of new algorithms and the increase in computing power to incorporate the rich heterogeneity of patterns from the micro data even in models where no aggregation to a representative firm or consumer is feasible. A defining characteristic of these models, though, is neither the heterogeneity among model agents they accommodate nor the micro-level evidence they rely on, although both are common, but rather the insistence that any new parameters or feature included be explicitly disciplined by direct evidence. The spirit of the discipline of the parameters of these third- 
generation models echoes the attitudes of the original developers of first-generation models, except that third-generation models are sophisticated enough to match a wealth of additional aspects of the micro data. The growth of such third-generation models was hastened by the Great Recession, a striking episode that led macroeoconomists to dig more deeply than before into the links between disruptions in the process of financial intermediation and business cycles.

In the final sections of the paper, we show how two versions of this latest generation of modern business cycle models with frictions in labor and financial markets can account, respectively, for the aggregate and the cross-regional fluctuations observed in the United States during the Great Recession. We begin with a comparison of the comovements of the major macro aggregates in the two largest post-war recessions in the United States: the 1982 recession, which exhibited essentially no financial distress, and the Great Recession, which was characterized by the greatest distress of any post World War II business cycle. In the 1982 recession, the drop in measured total factor productivity was as large as the drop in output, whereas hours fell much less than output, which amounts to a pattern that holds up across most postwar recessions. The pattern of these variables in the Great Recession was, instead, strikingly different: measured total factor productivity barely fell, whereas labor fell more than output. We argue that this fundamental difference in the pattern of comovements of output, measured productivity, and hours in the Great Recession, along with the documented increase in financial distress, calls for new mechanisms to explain this downturn.

Along with these specific examples, our overall message is that the basic questions that macroeconomists address have not changed over time, but rather that the development of real business cycle methods has fundamentally changed how these questions are posed and answered. Now, we no longer ask, "What is the best policy action we can take today?" but instead ask, "How does the behavior of the economy considered compare under one rule for policy versus another rule for policy?" We answer these questions with models that are specified at a deep enough level that their primitive features are plausibly invariant to the policy exercises of interest, as well as shown to be consistent with a wealth of relevant micro evidence.

Of course, macroeconomists still hold widely divergent views about the answers to fundamental questions such as the ability of a well-specified rule for monetary policy to single-handedly stop an 
incipient Great Depression episode in its tracks. But we now agree that a disciplined debate of such questions rests on communication in the language of a dynamic general equilibrium model specified at the level of primitives and internally as well as externally validated. Through such a disciplined communication, we can reduce endless debates about opinions to concrete ones about the evidence for detailed mechanisms and parameters.

\section{First Generation: Basic Real Business Cycle Models}

Modern business cycle models were developed in response to the Lucas critique of large-scale econometric models built along traditional Keynesian lines, which were the dominant scientific paradigm in macroeconomics from the 1950s to the 1970s. Lucas (1976) argued that unless an econometric model is built at a deep enough level so that its parameters are invariant to the class of policy interventions being considered, the model is of no value in assessing policy interventions, regardless of how well the model performs in unconditional forecasting. The reason is that the policy intervention may affect key parameters that are presumed to be constant, and so invalidate the policy exercise. This critique motivated macroeconomists to micro-found their dynamic models by building them starting from the specification of technology, preferences, and other primitive constraints, along with an equilibrium concept. In the resulting equilibrium, agents think intertemporally, not just statically, and decisions on consumption, investment, and labor supply must simultaneously satisfy resource constraints and budget constraints.

From a practical viewpoint, this Keynesian macroeconometric framework fell out of favor after the period of stagflation that many developed economies experienced during the 1970s. The reason is that this framework offered neither a cohesive theoretical explanation for this stagflation episode nor, in light of the Lucas critique, defensible policy advice.

\subsection{Early Attempts to Match Aggregate Macro Variables}

The first generation of modern business cycle models consisted of simple, primarily real business cycle models with a representative consumer and few frictions, which were used to examine the extent to which a small number of shocks, say, one or two, could account for the movements of major aggregates, such as output, consumption, investment, and hours. In this framework, all economic behavior 
was derived from one general equilibrium model, in which agents adjust their behavior when policies, specified as rules, are changed, and forecast the future using the true probability distributions implied by the model. A prominent example of such a model is in Prescott (1986), which features a representative consumer, one real exogenous technology shock, frictionless markets, and no money or nominal variables. Earlier versions of first-generation business cycle models by Kydland and Prescott (1982) and Long and Plosser (1983) featured much more complex real sides of the economy.

The early papers in this vein documented patterns in the macro data, typically summarized by a table of moments of the data such as standard deviations, autocorrelations, and cross-correlations of output, consumption, investment, hours, and a few other variables. This table, often referred to as a $K P$ table in light of Kydland and Prescott (1982), compared these moments in the data to those generated by the model. Key discrepancies between the predictions of the model and the actual data were often referred to as an "anomaly." For example, a key anomaly of the early work was that hours in the models fluctuated by less than half as much as in the data.

A typical research paper of this generation usefully focused on showing how adding one new mechanism to an otherwise standard model helped the model to better account for some existing anomaly. Over time, the work evolved into the study of richer mechanisms. The work in this vein seriously attempted to discipline new parameters with external evidence, which often involved connecting the new parameters considered to those from micro studies. Nonetheless, the models were sufficiently simple that it was often difficult to tightly connect features or implications of new mechanisms with the requisite evidence from micro-level data on consumers and firms.

The simple real business cycle models of that time with only stochastic movements in total factor productivity generated fluctuations in the major aggregates largely in accord with those observed in the data, when the technology parameter was simply taken as exogenous. As the Kydland and Prescott (1982) paper makes abundantly clear, they were surprised that their simple model, which abstracted from monetary frictions, could do so. However, this approach also gave rise to some oft-repeated questions about their purpose and design which we discuss next. 


\subsection{Why Abstract from Money?}

Why did early practitioners of the real business cycle approach focus on models that abstracted from money and, hence, monetary policy? There are three reasons. First, the goal of this early work was to develop the simplest possible model based on a coherent set of assumptions, in which agents acted in their own self interest and that could produce fluctuations in aggregate quantities, such as output, consumption, investment, and hours, broadly in accordance with those in the data. Second, the simplicity of the models reflected existing limits on the ability to numerically compute these models. In the late 1970s, macroeconomists lacked the methods and computing power to solve complicated models with heterogeneous agents, various frictions, and nonlinear effects. Third, many of the macroeconomists working on real business cycles were deeply affected by the failures of the policy advice derived from the earlier statistical Keynesian models that helped to exacerbate the stagflation of the 1970s. Hence, they retreated to a humbler intellectual position focused on building coherent foundations for macroeconomics and avoiding both the Lucas critique and the hubris that led to previous mistakes. Most macroeconomists felt quite uncomfortable rushing back to the policy arena without well-developed models.

Sometimes it is thought that the most important reason why real business cycle modelers abstracted from money was because they believed that monetary policy has no effect on the real economy. (See, for example, Summers 1986 and Romer 2016.) We argue that this view is incorrect. Part of the misunderstanding seems to have arisen from the well-known policy ineffectiveness proposition of Sargent and Wallace (1975). Sargent and Wallace articulated a critique of models that produced real effects of money solely because agents were assumed to be irrational.

In a similar vein, Barro (1977) critiques "sticky wage" models. He argues that even if nominal wages do not vary with monetary shocks, if we model wages and employment levels as part of a contract that is mutually agreed upon by firms and workers, then there is no room for monetary feedback rules to systematically improve outcomes. Barro points out a weak theoretical link in a popular mechanism: even if sticky nominal wages are assumed, existing models generate real effects solely because they assume that the employment contract does not specify hours worked in addition to wages and so leaves 
unexploited mutual gains from trade.

Properly understood, both Sargent and Wallace (1975) and Barro (1977) were critiques of popular existing mechanisms for monetary nonneutrality rather than the expression of either a belief that no coherent model could be developed in which monetary policy had real effects or that in actual economies monetary policies have no real effects. For example, there is near-universal agreement that the disastrous monetary policies pursued by countries such as Argentina, Brazil, and Chile had serious adverse effects on these economies.

More broadly, macroeconomists agree on the direction in which monetary policy should respond to shocks over the cycle-although they disagree on the magnitude of desirable monetary interventions. Even with a general agreement on how monetary policy works in a qualitative sense, it remains an exceptionally difficult task to build a coherent model in which consumers and firms act in their own self-interest and that quantitatively captures well how monetary policy works. For instance, as Barro (1977) foresaw, the difficulty with many of the sticky wage or price models is that they rely on agents agreeing to contracts that ignore mutual gains for trade. At a deeper level, the fact that a contract in such models is not optimal given preferences, technology, and information makes them subject to the Lucas critique. Our own sense is that depending on the exact standard that needs to be met before the word coherent is applicable, macroeconomists may still be a decade or two away from achieving that goal of having a coherent model.

\subsection{Why Focus on Technology Shocks?}

Real business cycle models are driven by what are commonly referred to as technology shocks. Why did early researchers choose to treat the aggregate productivity parameter in the output production function as the key stochastic variable? There are two practical reasons. First, productivity is relatively easy to measure, given a functional form assumption for the aggregate production function, data on aggregate output, the capital stock, and hours. Second, with a single shock added nearly anywhere else in a one-sector growth model, it is difficult to generate the business cycle comovements between output, consumption, investment, and hours found in the data.

For example, a shock that primarily leads to a deep fall in investment tends to make consumption 
and investment move in opposite directions, which is inconsistent with the data. To see why, consider the effect of a fall in investment on output. Since the capital stock is over 10 times investment, a drop in investment has only a tiny effect on the capital stock and no direct effect on labor, so the amount produced with capital and labor barely moves. But from the resource constraint, consumption and investment must add up to output. Hence, the only way that investment can fall a lot, output barely move, and the resource constraint be satisfied is for consumption to rise. Using a quantitative model, Cooper and Ejarque (2000) show that shocks that operate through an investment channel counterfactually imply that consumption and investment are negatively correlated.

Consider next a shock that reduces the desire to work and, hence, reduces hours. With a CobbDouglas aggregate production technology and a labor share of two-thirds, a given percentage drop in hours, say 10 percent, leads to only two-thirds (6.7 percent) as large a drop in output. But if such shocks are the main drivers of the business cycle, then labor would be much more volatile than output, an implication that is inconsistent with US business cycles prior to the Great Recession. (See Chari, Kehoe, and McGrattan 2007 and Brinca, Chari, Kehoe, and McGrattan 2016.)

Finally, it is also important to understand how this time-varying aggregate productivity parameter should be interpreted. From the beginning of modern business cycle theory, it was well accepted that movements in this parameter should not be interpreted as changes in "technology." That is, falls in measured total factor productivity should not be thought of as individual firms forgetting how to produce or deteriorations in the blueprints at the firm level for turning capital and labor into output. Rather, the time variation of the productivity parameter has always been thought of as a stand-in for deeper models of how economic outputs and inputs adjust to various nonproductivity shocks.

For one example, Lagos (2006) shows that in a standard search model with only firm-level productivity differences, an increase in either employment subsidies or costs of firing workers decreases the cutoff for how productive an individual firm must be in order to operate. Hence, these policies lead the average productivity of firms to fall and, hence, lead to a fall in total factor productivity. For another example, Chari et al. (2007) consider an increase in input financing frictions across sectors in that in bad times in some sectors, the cost of borrowing rises relative to that in other sectors. This financing friction distorts the mix of each sector's input in final output and hence gives rise to measured falls in 
total factor productivity.

An alternative view is that neither of these approaches is necessary to understand drops in measured total factor productivity because this measured drop mostly disappears if we simply adjust for the fall in capital utilization, $u_{K t}$, in downturns. To see how this argument works, let $u_{K t} K_{t}$ be the service flow from the capital stock, $K_{t}$, and $Y_{t}=A_{t}\left(u_{K t} K_{t}\right)^{\alpha} L_{t}^{1-\alpha}$ be a Cobb-Douglas production function. Clearly, drops in $u_{K t}^{\alpha}$ show up as drops in total factor productivity.

The challenge for this view is to provide a micro-founded reason for utilization to fall steeply enough during recessions to account for the measured fall in total factor productivity. The problem is that given that the vast bulk of a firm's expenses is for labor, keeping the capital stock running is typically much less expensive than paying for labor. Hence, quantitatively relevant micro-founded models often imply very modest declines in capital utilization during downturns. Moreover, since the capital share is small, say, $\alpha=25$ percent, such falls in capital utilization can account for only a very small fraction of the measured fall in total factor productivity. Of course, if in the data firms actually drastically reduce their capital utilization in recessions, then the puzzle is to explain why they do so. More theoretical work needs to be done in this area for progress to be made.

\section{Second Generation: For Central Banks with a New Keynesian}

\section{Twist}

The second generation of modern business cycle models consisted of medium-scale dynamic stochastic general equilibrium models, which were nearly all of the New Keynesian variety and much more complex than those of the first generation. The development of these models was driven by a desire from central banks around the world to find a practical replacement for the earlier large-scale Keynesian models. As a result, this new generation of medium-scale New Keynesian models needed to be conceived in a way that money could have real effects and be sophisticated enough that they could be used for forecasting.

These second-generation models were designed to fit the behavior of 10 or so aggregate time series that include output, consumption, investment, hours, and some nominal variables such as inflation and nominal interest rates. Because the metric for success in these models was their ability to reproduce 
the behavior of these aggregates, most of the effort in those models was expended on adding additional features—-such as one shock per equation, nonstandard adjustment costs, and extra parameters in preferences and technology - that allowed the model to fit in-sample properties of these aggregates. Little effort was devoted to ensuring that the added shocks, especially the unobservable ones, were clearly interpretable and that the added parameters were disciplined by an explicit attempt to validate them. In practice, these models featured such a complex mix of competing mechanisms, frictions, and shocks that they were quite difficult to understand. In this sense, the methodology for building and assessing second-generation models diverged sharply from that of first-generation models.

A more fundamental methodological issue with these second-generation models that deeply divides macroeconomists is how to build a model that is not subject to the Lucas critique. In practice, this means we need to ask, "What is a primitive enough level at which to specify a model so that the resulting model is arguably invariant to the policy interventions of interest?" For first-generation modelers, this level consists of technologies, including commitment technologies, preferences, information structure, and physical constraints, such as capital adjustment costs. After these objects are specified, agents are free to choose the contracts to sign or the assets to trade, subject to these primitive frictions. Secondgeneration modelers, instead, appended direct restrictions on contracts, such as particular forms of sticky wage contracts or restrictions on the class of asset trades allowed, even though these restrictions are not in anyone's interest given the primitive frictions.

For example, a second-generation model may assume that private contracts cannot depend on observable variables outside of any single agent's control, such as aggregate output, and then argue that such a restriction justifies government intervention in the form of a state-contingent tax policy to partially restore the effective insurance not provided by private contracts. From the point of view of a first-generation modeler, this approach is problematic, since the government intervention may affect the unspecified premise of why certain behavior is infeasible and so give rise to perverse incentives or unintended undesirable consequences. For example, if the true reason such a private contingent contract is infeasible is that it violates an unspecified incentive constraint, then the uncontingent contract that is made contingent by the government policy also violates the same unspecified incentive constraint. (For an early exposition of a version of this view, see Barro 1977.) 
These new models are often presented as essentially traditional Keynesian models derived from maximizing behavior, which has led to some confusion. Even though the labels IS and LM are often attached to certain equations, it is crucial to understand that these second-generation modern business cycle models are built on the first-generation models, not on the Keynesian IS-LM model. That is, the New Keynesian models are simply real business cycle models with a few frictions added on. Thus, although it may be surprising to nonmacroeconomists, a canonical real business cycle model, augmented with money and flexible prices so that monetary policy can be meaningfully discussed, has essentially the same implications for the fraction of business cycle fluctuations explained by various shocks and, perhaps more surprisingly, the same implications for policy as a canonical New Keynesian model.

To see that real business cycle models and New Keynesian models both imply that technology shocks account for the vast bulk of fluctuations, consider two models. On the one hand, we have a classic real business cycle model by Prescott (1986). He compares the variance of detrended output in his model to the variance of detrended US output, and documents that 70 percent of the variance of the observed fluctuations in output in the US economy can be mechanically accounted for by productivity shocks (p. 16). On the other hand, using a state-of-the-art New Keynesian model, Justiniano, Primiceri, and Tambalotti (2010) find that technology shocks, here the sum of neutral and investment-specific technology shocks, account for 75 percent of the variance of output, which, somewhat surprisingly, is actually a higher percentage than that in Prescott's calculation. ${ }^{1}$ In sum, a typical New Keynesian model added several frictions and shocks, but at its core, the key driving force for business cycles is a real business cycle model. Indeed, in the state-of-the-art New Keynesian model by Justiniano et al. (2010 p. 134), monetary policy shocks account for only a negligible fraction of the movements in output. In short, a New Keynesian model is exactly as Justiniano et al. (2010 p. 134) describe: "It is a medium-scale DSGE model with a neoclassical core, augmented with several frictions."

In part, the belief that real business cycle and New Keynesian models are based on different sources of economic fluctuations may represent a confusion about labeling. Some New Keynesian models

\footnotetext{
${ }^{1}$ We view this model as an updated version of the highly cited paper by Smets and Wouters (2007), which itself is a descendant of the Christiano, Eichenbaum, and Evans (2005) paper. Briefly, Smets and Wouters (2007) exclude changes in inventories from their definition of investment and include the purchases of consumer durables in consumption rather than investment. Justiniano et al. (2010), instead, include both the change in inventories and the purchases of consumer durables in investment. In other respects, the models are essentially identical.
} 
like Smets and Wouters (2007) and Justiniano et al. (2010) refer to investment-specific technology shocks as demand shocks, even though they represent shifts in the production function for the supply of investment goods, which might naturally seem to be types of supply shocks. Given the possibility for confusion on this point, these terms may have lost their usefulness. ${ }^{2}$

A second point is that under the popular narrative, New Keynesian models and flexible price models have radically different implications for monetary policy: in New Keynesian models, activist monetary policy is necessary to reduce the volatility of output and offset reductions in demand, whereas in flexible price models, monetary policy has no such role. We contend that this narrative reflects a deep misunderstanding of the workings and implications of these models. The genesis of this misunderstanding may be traced to the way New Keynesian models were presented, namely as traditional Keynesian models of the IS-LM variety but with maximizing agents.

This contention has been proven by Correia, Nicolini, and Teles (2008). These authors show that the monetary and fiscal policy implications of a flexible price model and a standard New Keynesian model in which prices are sticky are identical. The flexible price model is a real business cycle model with essentially neutral money added on, in that money has little effect on output, in which consumers can purchase some goods with cash obtained in advance and some other goods with credit—referred to as a cash-credit cash-in-advance model. The model features stochastic productivity shocks and stochastic government spending, as in Lucas and Stokey (1983), modified to have differentiated varieties of a single consumption good sold by monopolistic competitors. The New Keynesian model is an identical model except that prices are sticky in that producers are allowed to adjust their prices only at random (Poisson) times. The set of instruments available to the government are the money supply (or equivalently, nominal interest rates) and state-contingent linear taxes on consumption and labor income.

The main result is that in both models, it is optimal to have identical policies: constant (producer) prices and set tax rates to smooth distortions by equating the relevant margins over time. Critically, if an outside observer had data from this sticky price economy under such an optimal policy, fluctuations

\footnotetext{
${ }^{2}$ For another example in which this terminology is less than helpful, consider a constant elasticity of substitution demand function for a differentiated product $y^{d}=(p / P)^{-\theta} Y$, where $p$ is the price of that product, $P$ is the aggregate price index, and $Y$ is aggregate output. From the point of view of an individual producer, shifts in $Y$ are shifts in that producer's demand curve, even when these shifts in $Y$ come from aggregate productivity shocks. Here again, demand and supply terminology is not helpful.
} 
in all aggregates would be identical to those generated by a frictionless real business cycle model, adjusted to include neutral money. The reason is that in the original sticky price economy, optimal monetary policy is not attempting to offset real shocks to the economy, but instead is attempting to reproduce the flexible price allocations of the frictionless version of the model.

An immediate corollary of the work of Correia et al. (2008) is that the zero lower bound constraint, namely the constraint that nominal interest rates cannot be negative, has no impact on the equivalence of policy in New Keynesian and flexible price models. Hence, when taxes are set optimally the idea that the zero lower bound constraint makes increasing government spending more attractive than otherwise does not hold either. (See Correia, Farhi, Nicolini, and Teles for details.)

Finally, it is commonly argued that it is interesting to deprive the government of nearly all fiscal instruments when analyzing monetary policy because, in practice, it is difficult to quickly adjust fiscal policy in the depths of a recession. We argue that at least for deep recessions, this claim is not true: witness the speed at which the Obama Stimulus program, formally, the American Recovery and Reinvestment Act of 2009, was passed. Regardless of the merits of this program, it was clearly passed quickly enough to affect the economic recovery.

In sum, New Keynesian models are most certainly not reincarnations of textbook IS-LM models with maximization added on. Rather, they are real business cycle models augmented with a couple of distortions-typically sticky prices and monopoly power-and shocks that do little to contribute to fluctuations or influence the nature of optimal policy.

\section{Third Generation: Matching Aggregate Time Series Combined with External Validation}

The goal of second-generation models, nearly all New Keynesian ones, was to help central banks in their medium-term forecasting and allow central banks to use them for counterfactual policy experiments in order to inform the policy debate. In contrast, the goal of third-generation models is to develop new and more deeply founded mechanisms that formalize alternative possible explanations for business cycles as well as provide convincing external validation for the quantitative importance of these newly formalized mechanisms. 
Indeed, the hallmark of the third generation of modern business cycle models is their focus on an explicit external validation of their key mechanisms, using evidence independent of the particular aggregate time series for which the model is designed to account. Many of these third-generation models incorporate micro-level heterogeneity and are built on a tight connection between the mechanism in the model and the wealth of micro-level data pertinent to the key forces in the model. A defining characteristic of these models, though, is neither the heterogeneity among model agents they accommodate nor the micro-level evidence they rely on, although both are common, but rather their insistence that any new parameters or feature included be explicitly disciplined by direct evidence. In this sense, the spirit of the discipline of third-generation models echoes the attitudes of the original developers of firstgeneration models, except that third-generation models are sophisticated enough to match a wealth of additional aspects of the micro data and, in contrast to the first-generation models, do not need to be able to be aggregated to be solved.

More broadly, third-generation models grew naturally out of the first-generation ones. Thirdgeneration models have become feasible to explore only now because of the development of sophisticated algorithms and the advent of high-powered computers to compute them. Several decades ago, if a researcher was interested in a nonlinear model with both idiosyncratic and aggregate shocks, it was necessary to make assumptions so that the heterogeneity could be aggregated back to a suitably defined representative consumer and firm.

For example, in the classic model by Bernanke, Gertler, and Gilchrist (1999), even though banks are heterogeneous in their net worth, the model aggregates in that the only state variable of banks that needs to be recorded is aggregate net worth. The reason is that the model is carefully set up so that the value functions are linear in net worth. With new algorithms and greater computing power, it is feasible to compute such models even if they do not aggregate, so that the relevant aggregate state is the entire distribution of net worth across firms.

Many observers thought that the Great Recession would have led to an upheaval in macroeconomic modeling (for example, Christiano 2016). After all, these observers argued, much of the observed contraction in output was driven by disruptions in credit markets that spilled over into the real economy, but nearly all business cycle models featured no such links between financial and real activity. We argue 
that no upheaval ever happened: in contrast to the Great Stagflation of the 1970s, the Great Recession had essentially no impact on macroeconomic methodology per se. Rather, the Great Recession simply prompted macroeconomists to design models that elevated financial frictions from their previously modest role in amplifying the effects of other shocks, as in the classic work by Bernanke et al. (1999), to playing a central role in amplifying the shocks generating downturns. ${ }^{3}$ The main consequence of the Great Recession was to push macroeconomists further away from the medium-scale New Keynesian models with hard-to-interpret shocks and frictions, chosen mainly for their ability to fit macro aggregates, back to more elaborate versions of first-generation models of behavior modeled from primitives, which are then internally disciplined and externally validated by looking at their detailed implications for the data.

Although there are now many fine examples of third-generation models, below we discuss two examples of third-generation work with which we are most familiar. ${ }^{4}$ In both examples, the use of micro-level data is used to discipline the models' new features and assess how the proposed mechanisms are borne out in the relevant data on consumers and firms. The illustration in the next section draws on the work of Arellano, Bai, and Kehoe (forthcoming), which is motivated both by micro-level and macro-level patterns of firm behavior and by the Great Recession of 2007-2009, which we first review. The illustration in the following section focuses on the work of Kehoe, Midrigan, and Pastorino (forthcoming), which is motivated by the challenge for business cycle models to account for the cross-regional patterns of employment, consumption, and wages witnessed in the Great Recession.

Before reviewing these two examples, we compare the comovements of aggregates across the two largest postwar US recessions: the 1982 one and the Great Recession.

\footnotetext{
${ }^{3}$ A vibrant literature in international macroeconomics had already developed open economy models that included financial crises. However, the mechanisms explored in this work were not immediately applicable to the pattern of crises witnessed in large developed economies such as the United States. The reason is that the patterns of crises in small emerging markets pointed to the central role of issues like a sudden stop of capital inflows (Mendoza 2010) and possible defaults on sovereign debt (like Cole and Kehoe 2000; Arellano 2008; Neumeyer and Perri 2005). These issues are clearly relevant to episodes in Argentina, Mexico, and Greece but they played essentially no role in the US Great Recession.

${ }^{4}$ An important hybrid of second- and third-generation approaches is the work of Kaplan, Moll, and Violante (2018), which incorporates heterogeneous consumers into a New Keynesian model. On the one hand, whereas the costs of purchasing illiquid assets are disciplined by consumers' responses to unanticipated tax rebates, the key features of the model, namely the consumers' heterogeneous responses to monetary shocks, are not disciplined by the data. Moreover, computational limitations force the authors to consider only one-time unanticipated shocks, so that the implications of the model for business cycles are not yet known.
} 


\subsection{Classifying and Modeling Recessions: 1982 and the Great Recession}

In terms of understanding and accounting for the Great Recession, two questions arise. First, can the Great Recession be thought of as a financial recession in a way that earlier large recessions such as the 1982 recession cannot be? Second, do the patterns of comovement between, say, output, hours, and productivity differ across financial and nonfinancial recessions?

To answer the first question, we draw on the work of Romer and Romer (2017), who argue that the 1982 recession in the United States exhibited no financial distress, whereas the Great Recession in the United States displayed some of the greatest financial distress in the entire post-World War II sample of developed countries. Romer and Romer (2017) construct a financial distress measure based on a real-time narrative source, the OECD Economic Outlook, to identify the severity crisis by the size of the change of various indicators, including increases in the costs to financial institutions in obtaining funds and general increases in the perceived riskiness of financial institutions.

These authors show that throughout the entire 1982 recession, the distress measure for the United States indicated their lowest possible level of distress, namely no distress. Throughout the Great Recession, instead, this same measure indicates a growing level of distress that peaks in 2008 at a level indicating extreme financial distress. These two recessions are then clean cases to compare for the United States in terms of the comovements of macro aggregates, since they are the two deepest postwar recessions the country experienced, and they display the opposite extremes in the amount of financial distress. ${ }^{5}$

As panel A of Figure 1 shows, while the 1982 recession was somewhat deeper than the Great Recession, the downturn following the Great Recession was much more persistent. ${ }^{6}$ The more basic question is whether the patterns of comovements among the major aggregates differ between financial

\footnotetext{
${ }^{5}$ In terms of modeling financial distress, an important issue is that of reverse causation. Regardless of the underlying cause, the deeper a recession is, the more likely that firms and households that contracted uncontingent loans will find it hard to repay them and, hence, the more likely that the financial institutions that extended such loans will experience financial distress. Moreover, the feedback is highly likely to go both ways: underlying causes, perhaps only partially financial, generate financial distress, which, in the presence of financial frictions, exacerbate the real downturn and lead to more distress. In short, an open question is whether the financial crisis is the result of a "shock" in the sense of a economy-wide run on financial institutions or whether financial frictions amplify other shocks and, hence, give rise to severe financial distress.

${ }^{6}$ Some economists, such as Taylor (2016), argue that the causes of this slow growth are not directly connected to the financial crisis that accompanied the Great Recession.
} 
and nonfinancial recessions to the point where a different mechanism is called for that is different from those that conventionally account for most of the other postwar recessions. The short answer is "yes."

The comovements among output, hours, and total factor productivity in the Great Recession in the United States differed from earlier recessions: compared to the 1982 recession, in the Great Recession the drop in total factor productivity was much smaller relative to the drop in output, whereas the drop in hours was much larger and longer-lasting than the drop in output. In terms of mechanisms, these patterns imply that the 1982 recession was characterized by the typical pattern of most postwar recessions, which can be mechanically accounted for by drops in total factor productivity, whereas the pattern in the Great Recession cannot be. This latter recession, instead, seems to suggest the need for a mechanism that makes labor fall much more relative to output than it does in both typical recessions and in standard models. (See Brinca et al. 2016.)

As for the data, the two panels of Figure 2 illustrate this difference. In panel A, we graph output detrended by a 1.6 percent trend and non-detrended hours, both normalized to 100 in 1979:Q1. We see that, relative to 1979:Q1, output falls about 10 percent and hours falls about 6 percent so that the decline in hours is much smaller than the decline in output. In panel B, we graph output for the Great Recession detrended by a 1.6 percent trend, as well as non-detrended hours, both normalized to 100 in 2007:Q3. Comparing the levels in 2007:Q3 to those in the subsequent trough, output falls about 7 percent and hours falls about 9 percent. Critically, during the Great Recession the decline in hours is larger than the decline in output. Since standard real business models imply that for any given productivitity shock, the percentage fall in hours is less than half of that in output, such models simply cannot account for the patterns of comovements in the Great Recession.

In sum, the 1982 recession, which exhibited no financial distress, was a typical real business cycle recession. $^{7}$ In contrast, the Great Recession, which exhibited financial distress that was an order of magnitude larger than all other postwar US recessions, had a modest fall in measured total factor productivity but a fall in hours greater than the fall in output.

\footnotetext{
${ }^{7}$ Note that as Chari et al. (2007) stress, since measured fluctuations in total factor productivity are best thought of as efficiency wedges, namely, reduced-form shocks that arise from the interaction of frictions with primitive shocks, this finding could be consistent with the view that the decline in measured total factor productivity was generated by a monetary policy reaction to nontechnology shocks.
} 


\subsection{A Mechanism for the Patterns of Comovements during the Great Recession}

\subsubsection{Evidence for and Description of a New Mechanism}

Any mechanism that accounts for the Great Recession must generate a large downturn in output associated with a sharp fall in hours, must generate a small decline in measured productivity, and must also be consistent with a large rise in measured financial distress.

One striking feature of the micro data on the Great Recession is that the financial crisis during the Great Recession was accompanied by large increases in the cross-section dispersional of firm growth rates (see Bloom, Floetotto, Jaimovich, Saporta-Eckstein, and Terry 2014). Indeed, as panel B of Figure 1 shows, the increase in the interquartile range of firms' sales growth during the Great Recession was nearly triple that during the 1982 recession. As credit conditions tightened during the financial crisis, firms' credit spreads increased, whereas both equity payouts and debt purchases decreased. Motivated by these observations and the patterns of comovement described earlier, Arellano et al. (forthcoming) build a model with heterogeneous firms and financial frictions, in which increases in volatility at the firm level lead to increases in the cross-sectional dispersion of firm growth rates, a worsening of financial conditions, and a decrease in aggregate output and labor associated with small movements in measured total factor productivity.

The key idea in the model is that hiring inputs to produce output is risky: firms must hire inputs before they receive the revenues from their sales. To hire these inputs, firms must pledge to use some of their future revenues to pay for them. In this context, (owners of) a firm face the risk of any idiosyncratic shock that occurs between the time of production and the receipt of revenues. When financial markets are incomplete in that firms have only access to debt contracts to insure against such shocks, firms and their creditors must bear this risk, which has real consequences if firms must experience a costly default once they cannot meet their financial obligations. In the model, an increase in uncertainty arising from an increase in the volatility of idiosyncratic productivity shocks at the firm level makes the revenues from any given amount of labor hired more volatile and, thus, a default more likely. Thus, in equilibrium an increase in volatility leads firms to hire fewer inputs.

The model features a continuum of heterogeneous firms that produce differentiated products. The 
productivity of these firms is subject to idiosyncratic shocks with stochastically time-varying volatility; these volatility shocks are the only aggregate shocks in the economy. Three ingredients are critical to the workings of the model. First, firms hire their inputs—-here, labor-and produce before they know their idiosyncratic shocks. The insight that hiring labor is a risky investment is a hallmark of quantitative search and matching models but is missing from most simple macroeconomic models. Second, financial markets are incomplete in that firms have access only to state-uncontingent debt and can default on it. Firms face interest rate schedules for borrowing that depend on all the shocks; higher borrowing and labor hiring result in higher probabilities of default. Third, motivated by the work of Jensen (1986), the model includes an agency friction in that managers can divert free cash flow to projects that benefit themselves at the expense of firms. This friction makes it optimal for firms to limit free cash flow and, by so doing, makes firms less able to self-insure against adverse shocks.

In the model, the main result is that an increase in uncertainty arising from an increase in the volatility of idiosyncratic productivity shocks increases the volatility of the revenues from any given amount of labor hired. As the risk of default increases, firms cut back on hiring inputs. This result depends critically on the assumptions of incomplete financial markets and the agency friction. If firms had access to complete financial markets, firms would simply respond to a rise in volatility by restructuring the pattern of payments across states and, as Arellano et al. (forthcoming) show, both output and labor would increase sharply when volatility rises. Indeed, when the distribution of idiosyncratic productivity spreads out and shocks are serially correlated, firms with high current productivity shocks tend to hire relatively more of the factor inputs. It is only when the volatility of firm-level productivity shocks is accompanied by financial frictions that the model produces a downturn in output. Without agency costs, firms could self-insure by maintaining a large buffer stock of unused credit. Absent the agency friction, firms find it optimal to build up buffer stocks well in excess of those observed in the data. With it, however, find it optimal to limit the size of their buffer stocks and maintain debt levels consistent with those in the data. With such debt levels the model generates realistic fluctuations in labor.

Quantitatively, the authors investigate whether an increase in the volatility of firm-level idiosyncratic productivity shocks, which generates the increase in the cross-sectional dispersion of firm-level growth rates observed in the recent recession, leads to a sizable contraction in aggregate economic activity 
and tighter financial conditions. To do so, the authors choose a sequence of volatility shocks so that the model produces the same cross-sectional increase in sales growth as observed during the Great Recession. Figure 3A shows the resulting cross-sectional volatility of sales growth in the model and the data, where the latter is measured by the interquartile range of sales growth across firms. Figures 3B and $3 \mathrm{C}$ show that the model can account for essentially all of the contraction in output and labor that occurred in the Great Recession. Figures 3D, 3E, and 3F show that the model also does a reasonable job of reproducing the changes in financial variables that occurred during this period, as measured by credit spreads, debt purchases, and equity payouts. More generally, Arellano et al. (forthcoming) show that their model generates labor fluctuations that are large relative to those in output, similar to the relationship between output and labor in the data.

\subsubsection{Third-Generation Nature of the Exercise}

It is useful to contrast the Arellano et al. (forthcoming) approach linking the model to the micro data to that used in a well-cited second-generation approach to financial shocks and the Great Recession, namely, that of Christiano, Motto, and Rostagno (2017). This latter paper focuses on fitting 12 aggregate time series: GDP, consumption, investment, hours, inflation, wages, prices of investment goods, and the federal funds rate as well as four aggregate financial variables. The Christiano et al. (2017) paper represents the frontier work in that generation of work, but it never attempts to compare the detailed patterns of firm-level variables implied by the model to those in the data.

In contrast, the paper by Arellano et al. (forthcoming) takes a very different approach to the micro data. The authors start by showing that the model is consistent with some basic features of firms' financial conditions over the cycle, namely that firm spreads are countercyclical, as in the data, and that both the ratio of debt purchases to output and the ratio of equity payouts to output have similar correlations with output and volatility as in the data.

They then turn to micro moments of financial variables from the cross-sectional distribution of firms. Table 1 presents the time series median of spreads, the growth of sales, leverage, debt purchases, and equity payouts by each quartile. While there are some differences, this very simple model does a reasonable job of producing these moments. They also show that the correlations of firm-level leverage with firm-level credit spreads, sales growth, debt purchases, and equity payouts are similar in the model 
and the data.

\subsection{A Mechanism for the Regional Patterns in the Great Recession}

\subsubsection{Evidence for and Description of a New Mechanism}

An alternative and complementary insight into the Great Recession can be gained by exploring the distinctively different regional characteristics of the Great Recession in the United States. To that end, we first discuss the regional patterns of employment, consumption, and wages in the United States during that time. We then conclude by presenting a promising mechanism that accounts for the strongly differential response of different US states to the Great Recession.

During the Great Recession, the regions of the United States that experienced the largest declines in household debt also experienced the largest drops in consumption, employment, and wages (see, for example, Mian and Sufi 2011, 2014). Here, we focus on two main aggregate patterns. First, the regions of the United States that were characterized by the largest declines in consumption were also characterized by the largest declines in employment, especially in the nontradable goods sector. Second, the regions that experienced the largest employment declines also experienced the largest declines in real wages relative to trend.

The panels of Figure 4 summarize these patterns. Kehoe et al. (forthcoming) illustrate the first pattern by using annual state-level data on employment and consumption from the Bureau of Economic Analysis. In the spirit of the model, we isolate changes in consumption associated with changes in households' ability to borrow_or, more generally, in credit conditions — as proxied by changes in house prices, by projecting state-level consumption growth on the corresponding growth in state-level (Zillow) house prices. We use the resulting series for consumption growth in our analysis (for a similar approach, see Charles, Hurst, and Notowidigdo 2015).

Panel A of Figure 4, taken from Kehoe et al. (forthcoming), plots state-level employment growth between 2007 and 2009 against the measure of state-level consumption growth just described over this same period. The elasticity of employment to consumption is 0.38 . Panels $\mathrm{B}$ and $\mathrm{C}$ show that consumption declines are associated with relatively large declines in nontradable employment and essentially no changes in tradable employment across states: a 10 percent decline in consumption across states is 
associated with a 5.5 percent decline in nontradable employment and a negligible (and statistically insignificant) 0.3 percent increase in tradable employment. The large negative intercept in panel C shows that the decline in tradable employment is sizable in all states but unrelated to changes in state-level consumption.

The second main correlation is shown in panel D of Figure 4, which reproduces a version of the findings in Beraja, Hurst, and Ospina (2016). These authors document that wages were moderately flexible in the cross section of US regions: the cross-regional decline in wages was almost as large as the decline in employment. We closely follow their approach by using census data for wages from the Integrated Public Use Microdata Series, and controlling for observable differences in workforce composition both across states and within a state over time, as in Beraja et al. (2016). As panel D shows, a decline in employment of 10 percent across US states during the Great Recession is associated with a decline in wages of 7.8 percent.

To investigate these cross-regional patterns, Beraja et al. (2016) use what they term a semi-structural methodology, which uses a simple general equilibrium model together with a combination of regional and aggregate data to identify the regional and aggregate shocks driving business cycles. In particular, based on detailed census data at the household level on employment and wages, they find that, in the cross section, in regions where hours worked fell relatively more, nominal and real wages fall relatively more. These authors also show that shocks to the intertemporal marginal rate of substitution, called discount factor shocks, can account for the vast bulk of the cross-regional variation in employment in the United States during the Great Recession. The idea of using shocks to the discount factor as a proxy for variations in financial risk in the context of the Great Recession was also used by Hall (2017). ${ }^{8}$

By developing an approach to exploring these cross-regional patterns that is complementary to Beraja et al. (2016), Kehoe et al. (forthcoming) investigate how the interplay between credit and labor market frictions can account for the cross-sectional patterns just documented. We develop a version of the Diamond-Mortensen-Pissarides search model with risk-averse agents, borrowing constraints, and human capital accumulation. The underlying idea is that hiring workers is an investment activity: costs

\footnotetext{
${ }^{8}$ Here we have discussed one class of models that accounts for aggregate movements and another that accounts for crosssectional movements. For an interesting model that attempts to account for both at the same time see Jones, Midrigan, and Phillipon (2017).
} 
of creating vacancies are paid up front, whereas benefits, as measured by the flows of surplus from the match between a firm and worker, accrue over time. In this framework, a credit tightening generates a fall in investment—including investment related to hiring workers—which induces firms to post fewer vacancies and so causes employment in the aggregate to fall.

The key innovation here is the addition of human capital accumulation. In a textbook version of the Diamond-Mortensen-Pissarides search model without human capital accumulation, a large fraction of the present value of benefits from forming a match accrues early in the match. As a result, credit tightening has little effect on hiring in this model. But in the presence of human capital accumulation, the flows of benefits from forming a match have a much longer duration. Intuitively, a match not only produces current output but also augments a worker's human capital, with persistent effects on a worker's output flows (a finding that holds even if matches dissolve at a high rate). This significantly longer duration of surplus flows, or returns to employment, amplifies the drop in employment from a credit contraction, like the one observed during the Great Recession, by a factor of 10 relative to that implied by the model without human capital accumulation.

To build intuition for our new mechanism, consider a firm's incentives to post vacancies after a credit tightening that leads to a temporary fall in consumption. Since consumers have a desire to smooth consumption, this temporary fall in consumption increases consumers' marginal utility and hence their shadow price of current goods, which then mean-reverts. This temporary increase in the shadow price of goods has two opposing effects. First, it increases the cost of posting vacancies by raising the shadow value of the goods used in this investment. Second, it increases the surplus from a match by raising the shadow value of the surplus flows produced by a match. The cost of posting vacancies rises by more than the benefits because the cost of posting new vacancies is incurred immediately when goods are especially valuable, whereas the benefits accrue gradually in the future when workers acquire human capital with employment. As a result, firms post fewer vacancies, and in the aggregate employment contracts. The longer is the duration of the surplus flows from a match, the larger is the resulting drop in vacancies.

We show that the resulting model does an excellent job of reproducing the cross-state patterns in terms of the comovement of consumption and nontradable employment, tradable employment, and 
overall employment. The model is also consistent with the observation in Beraja et al. (2016) that in the cross section of US states, wages are moderately flexible: a 10 percent drop in employment is associated with a fall in wages of 7.8 percent in both the data and the model. Thus, the model predicts sizable employment changes in response to a credit tightening, even though wages are as flexible as they are in the data. As Beraja et al. (2016) emphasize, this finding of substantial wage flexibility in the data casts doubt on the popular explanations of the Great Recession in the New Keynesian literature.

\subsubsection{Third-Generation Nature of the Exercise}

It is helpful to contrast second- and third-generation approaches to understand the cross-regional features of the Great Recession discussed above.

The second-generation approach would simply imply choosing parameters for the human capital process so as to fit the state-level employment patterns observed in the data, without informing this choice with any specific micro evidence on the relationship between human capital accumulation and wage growth or verifying whether the inferred parameters are consistent with additional micro evidence.

Instead we proceed as follows. Because the process for human capital accumulation is critical for the model's predictions, we take great care in using micro data to quantify it. The top part of Table 2 illustrates how we use cross-sectional differences in wages from Elsby and Shapiro (2012) on how wages increase with experience and longitudinal data on how wages grow over an employment spell from Buchinsky et al. (2010) to discipline the model parameters.

The bottom part of Table 2 shows how we used other evidence, not directly targeted in our momentmatching exercise, to externally validate other features of the micro data. For example, we show that the model produces drops in wages after a nonemployment spell, the sensitivity of this wage drop to an additional year of tenure, the standard deviation of wages at the beginning of an employment spell, and the profit share of revenue similar to the corresponding measures in the data. We also show that the model is consistent with other such patterns, including the distribution of durations of nonemployment spells and the evidence on wage losses from displaced worker regressions (as in Jacobson, LaLonde, and Sullivan 1993).

Finally, we show the main result on the employment decline in response to a credit tightening is robust to a range of estimates of wage growth in the labor economics literature. 
Thus, this third-generation modern business cycle model introduces a new mechanism, human capital accumulation, for the amplification of the employment response to a credit crunch, and does so in a way that is disciplined by evidence that is external to the phenomenon to be explained, rather than just adding new parameters to better fit the main macroeconomic aggregates of interest.

\section{Conclusion: The Centrality of Shifts in Method}

The real business cycle revolution, at its core, was a revolution of method. It represents a move from an older econometric tradition underlying traditional Keynesian and Monetarist large-scale macroeconomic models, in which exclusionary restrictions in a system of equations were taken to be the primitive specification of behavior, toward an approach in which maximization problems for consumers and firms that are consistent with a notion of general equilibrium are taken to be the primitive specification of behavior.

It is most fruitful to think of this methodology as simply a highly flexible language through which modern macroeconomists communicate. The class of existing modern business cycle models using dynamic stochastic general equilibrium methods has come to include an enormous variety of work: real and monetary; flexible price and sticky price; financial or labor market frictions; closed and open economies; infinitely lived consumer or overlapping generations versions; homogeneous agent or heterogeneous agent versions; rational or robust expectations; time inconsistency issues at either the policymaker level or the individual decision maker level; multiple equilibria, constrained efficient equilibria, or constrained inefficient equilibria; coordination failures; and so on. Indeed, the language seems flexible enough to incorporate any well-thought-out idea.

What distinguishes individual papers that adopt this language, then, is not the broad methodology used, but rather the particular questions addressed and the specific mechanisms built into the model economy. For example, if one is interested in investigating optimal monetary policy in the face of financial shocks to the credit system, it is necessary to model monetary policy, financial shocks, and a credit system. But in every case, the unifying feature of real business cycles is their methodology-the specification of primitive technology, preferences, information structure, and constraints in an environment in which agents act in their own interest. 
Macroeconomists still have fundamental disputes, but they all revolve around methodology. In particular, some maintain that all restrictions on prices, wages, and contracts must arise from economic fundamentals, such as technologies, including commitment technologies, preferences, and information structure. For these macroeconomists, the existing sticky wage and sticky price models are not altogether satisfactory because, as Barro (1977) explained, even if wages and prices are sticky in that they cannot respond to shocks, there typically exist feasible and mutually beneficial contracts that dominate them. Once such contracts are adopted, the case for an activist monetary policy is strongly weakened. Such macroeconomists also find unappealing models in which debt contracts cannot depend on aggregate observable variables, such as output or region-wide house prices, even though these variables are outside the ability of any single agent to affect, so no moral hazard issue would arise if contracts depended on them. In these setups, they find particularly dubious the study of policies that simply allow the government to partially replicate outcomes that private agents should be naturally able to achieve by themselves.

More important, although macroeconomists often hold heterogeneous beliefs about how promising any particular mechanism may be in accounting for features of the data or about the benefits of any particular policy, they agree that a disciplined debate rests on communication in the language of dynamic general equilibrium theory. By so doing, macroeconomists can clarify the origins of any disagreement and hence make progress on how to settle them. For example, when two different views are justified by fully specified quantitative models, it is relatively easy to pinpoint which key parameters or mechanisms are at the heart of the differing conclusions for policy. Hence, future work can attempt to discern which is in greater conformity with the data. In sum, this approach turns disagreements about outcomes of policies, which are difficult to make scientific progress on without a model, into disagreements about fundamental parameters, which are easier to resolve.

In this sense, there is no crisis in macroeconomics, no earthquakes, no massive failure in methodology, no need for non-equilibrium logic or undisciplined frictions and shocks. Overall, modern macroeconomists live under a big tent that welcomes creative ideas laid out in a coherent language, specified at the level of primitives, and disciplined by external validation. 


\section{References}

Arellano, Cristina. 2008. Default risk and income fluctuations in emerging economies. American Economic Review 98 (3): 690-712.

Arellano, Cristina, Yan Bai, and Patrick Kehoe. Forthcoming. Financial frictions and fluctuations in volatility. Journal of Political Economy.

Barro, Robert J. 1977. Long-term contracting, sticky prices, and monetary policy. Journal of Monetary Economics 3 (3): 305-316.

Beraja, Martin, Erik Hurst, and Juan Ospina. 2016. The aggregate implications of regional business cycles. National Bureau of Economic Research Working Paper 21956.

Bernanke, Ben S., Mark Gertler, and Simon Gilchrist. 1999. The financial accelerator in a quantitative business cycle framework. In Handbook of Macroeconomics 1, Vol. 1, edited by John B. Taylor and Michael Woodford, 1341-1393. Amsterdam: Elsevier.

Bloom, Nicholas, Max Floetotto, Nir Jaimovich, Itay Saporta-Eksten, and Stephen Terry. 2014. Really uncertain business cycles. Unpublished paper, Stanford University.

Brinca, Pedro, V.V. Chari, Patrick J. Kehoe, and Ellen R. McGrattan. 2016. Accounting for business cycles. Handbook of Macroeconomics, Vol. 2A, edited by John Taylor and Harald Uhlig, 1013-1063. Amsterdam: North Holland.

Buchinsky, Moshe, Denis Fougere, Francis Kramarz, and Rusty Tchernis. 2010. Interfirm mobility, wages and the returns to seniority and experience in the United States. Review of Economic Studies 77 (3): $972-1001$.

Chari, V.V., Patrick J. Kehoe, and Ellen R. McGrattan. 2007. Business cycle accounting. Econometrica 75 (3): 781-836.

Charles, Kerwin Kofi, Erik Hurst, and Matthew J. Notowidigdo. 2015. Housing booms and busts, labor market opportunities, and college attendance. National Bureau of Economic Research Working Paper 21587.

Christiano, Lawrence J. 2016. The Great Recession: Earthquake for macroeconomics. Macroeconomic Review 15 (1): 87-96.

Christiano, Lawrence J., Martin Eichenbaum, and Charles L. Evans. 2005. Nominal rigidities and the 
dynamic effects of a shock to monetary policy. Journal of Political Economy 113 (1): 1-45.

Christiano, Lawrence J., Roberto Motto, and Massimo Rostagno. 2017. Risk shocks. American Economic Review 104 (1): 27-65.

Cole, Harold L., and Timothy J. Kehoe. 2000. Self-fulfilling debt crises. Review of Economic Studies 67 (1): 91-116.

Cooper, Russell and João Ejarque. 2000. Financial intermediation and aggregate fluctuations: A quantitative analysis. Macroeconomic Dynamics 4 (4): 423-447.

Correia, Isabel, Emmanuel Farhi, Juan Pablo Nicolini, and Pedro Teles. 2013. Unconventional fiscal policy at the zero bound. American Economic Review 103 (4): 1172-1211.

Correia, Isabel, Juan Pablo Nicolini, and Pedro Teles. 2008. Optimal fiscal and monetary policy: Equivalence results. Journal of Political Economy 116 (1): 141-170.

Elsby, Michael W. L., and Matthew D. Shapiro. 2012. Why does trend growth affect equilibrium employment? A new explanation of an old puzzle. American Economic Review 102 (4), 1378-1413.

Hall, Robert E. 2017. High discounts and high unemployment. American Economic Review 107 (2): 305-330.

Jacobson, Louis S., Robert J. LaLonde, and Daniel G. Sullivan. 1993. Earnings losses of displaced workers. American Economic Review 83 (4): 685-709.

Jensen, Michael C. 1986. Agency costs of free cash flow, corporate finance, and takeovers. American Economic Review 76 (2): 323-329.

Jones, Callum, Virgiliu Midrigan, and Thomas Philippon. 2017. Household leverage and the recession. Unpublished paper, New York University.

Justiniano, Alejandro, Giorgio E. Primiceri, and Andrea Tambalotti. 2010. Investment shocks and business cycles. Journal of Monetary Economics 57 (2): 132-145.

Kaplan, Greg, Benjamin Moll, and Giovanni L. Violante. 2018. Monetary policy according to HANK. American Economic Review 108 (3): 697-743.

Kehoe, Patrick J., Virgiliu Midrigan, and Elena Pastorino. Forthcoming. Debt constraints and employment. Journal of Political Economy.

Klein, Lawrence R., and Arthur S. Goldberger. 1955. An Econometric Model of the United States, 
1929-1952. Amsterdam: North Holland.

Kydland, Finn E., and Edward C. Prescott. 1982. Time to build and aggregate fluctuations. Econometrica 50 (6): 1345-1370.

Lagos, Ricardo. 2006. A model of TFP. Review of Economic Studies 73 (4): 983-1007.

Long, John B. Jr., and Charles I. Plosser. 1983. Real business cycles. Journal of Political Economy 91 (1): 39-69.

Lucas, Robert E., Jr., 1976. Econometric policy evaluation: A critique. Carnegie-Rochester Conference Series on Public Policy, Vol. 1, edited by Karl Brunner and Allan H. Meltzer, 19-46. Amsterdam: North-Holland.

Lucas Robert E., Jr., and Nancy L. Stokey. 1983. Optimal fiscal and monetary policy in an economy without capital. Journal of Monetary Economics 12 (1): 55-93.

Mendoza, Enrique G. 2010. Sudden stops, financial crises, and leverage. American Economic Review 100 (5): 1941-1966.

Mian, Atif, and Amir Sufi. 2011. House prices, home equity-based borrowing, and the US household leverage crisis. American Economic Review 101 (5): 2132-2156.

Mian, Atif, and Amir Sufi. 2014. What explains the 2007-2009 drop in employment? Econometrica 82 (6): 2197-2223.

Neumeyer, Pablo A., and Fabrizio Perri. 2005. Business cycles in emerging economies: The role of interest rates. Journal of Monetary Economics 52 (2): 345-380.

Prescott, Edward C. 1986. Theory ahead of business cycle measurement. Federal Reserve Bank of Minneapolis Quarterly Review, 10 (4): 9-22.

Romer, Christina D., and David H. Romer. 2017. New evidence on the aftermath of financial crises in advanced countries. American Economic Review 107 (10): 3072-3118.

Romer, Paul. 2016. The trouble with macroeconomics. Forthcoming in American Economist.

Sargent, Thomas J., and Neil Wallace. 1975. "Rational” expectations, the optimal monetary instrument, and the optimal money supply rule. Journal of Political Economy 83 (2): 241-254.

Smets, Frank, and Rafael Wouters. 2007. Shocks and frictions in US business cycles: A Bayesian DSGE approach. American Economic Review 97 (3): 586-606. 
Summers, Lawrence H. 1986. Some skeptical observations on real business cycle theory. Federal Reserve Bank of Minneapolis Quarterly Review 10 (4): 23-27.

Taylor, John B. 2016. Slow economic growth as a phase in a policy performance cycle. Journal of Policy Modeling 38 (4): 649-655.

Woodford, Michael. 2003. Interest and Prices: Foundations of a Theory of Monetary Policy. Princeton, NJ: PrincetonUniversity Press. 
Table 1: Firm-Level Distributions (Arellano et al., forthcoming)

\begin{tabular}{|c|c|c|c|c|c|c|}
\hline \multirow[b]{2}{*}{ Percentile } & \multicolumn{3}{|c|}{ Data (\%) } & \multicolumn{3}{|c|}{ Model (\%) } \\
\hline & 25 & 50 & 75 & 25 & 50 & 75 \\
\hline Spread & 1 & 1.3 & 2.1 & 1.1 & 2.8 & 6.3 \\
\hline Growth & -9 & 0 & 11 & -7 & 0 & 9 \\
\hline Leverage & 9 & 26 & 62 & 25 & 29 & 33 \\
\hline Debt purchases & -10 & 0 & 21 & -14 & 0 & 16 \\
\hline Equity payouts & -4 & 0 & 12 & -19 & 0 & 23 \\
\hline
\end{tabular}

Note: Leverage is the sum of short-term and long-term debt divided by average sales. Equity payouts are the ratio of the sum of dividends and net equity repurchases to average sales and debt. Debt repurchases are the ratio of the change in total firm debt to average sales. For both data (Compustat) and model, we report the median of the time series of the 25th, 50th, and 75th percentiles across firms, computed for each variable and quarter. Growth and dividends are reported relative to the median 50th percentile.

Table 2: Individual Wages and Profits (Kehoe et al., forthcoming)

\begin{tabular}{lcc}
\hline \hline Moments & Data & Model \\
\hline Targeted Moments & & \\
Cross-sectional difference in log wages & 1.21 & 1.19 \\
$\quad$ 30 to 1 years of experience & 0.10 & 0.10 \\
Annual wage growth during an employment spell & 0.07 & 0.08 \\
1-10 years of experience & 0.06 & 0.06 \\
11-20 years of experience & 0.06 & 0.05 \\
21-30 years of experience & 0.07 & 0.07 \\
31-40 years of experience & & \\
1-40 years of experience & $0.044-0.055$ & 0.05 \\
Moments for External Validation & 1.54 & 1.95 \\
Mean wage drop after nonemployment spell & 0.85 & 0.82 \\
Sensitivity of wage loss to one additional tenure year, $\%$ & 0.06 & 0.06 \\
Standard deviation of initial log wages & \\
Profit share of revenue &
\end{tabular}


Figure 1: Comparing 1982 Recession and Great Recession

A. Output

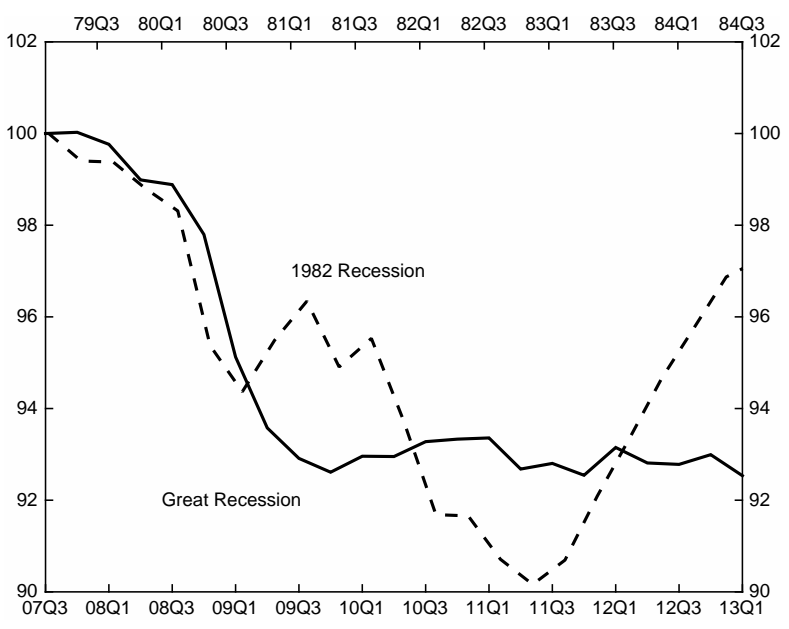

B. Interquartile Range of Firm-Level Sales Growth

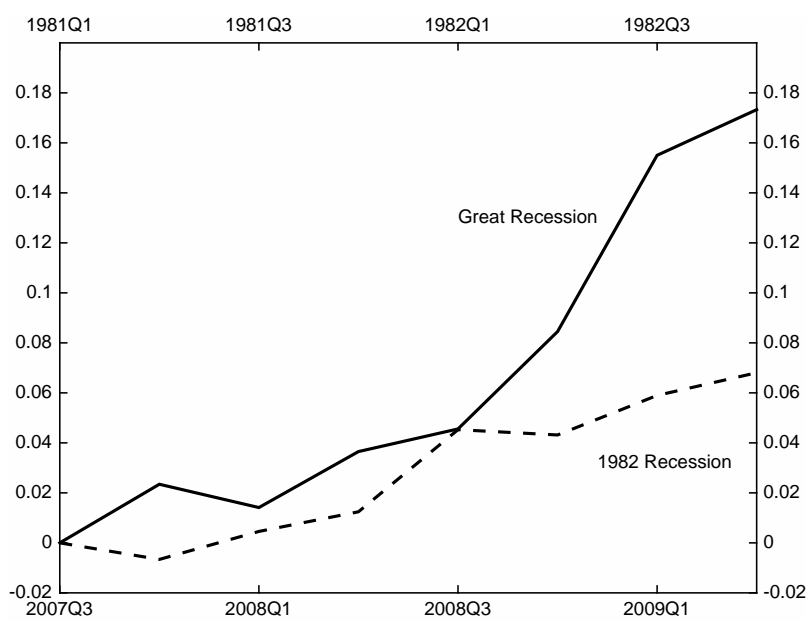

Figure 2: US Output and Hours

A. US Output and Hours in 1982 Recession

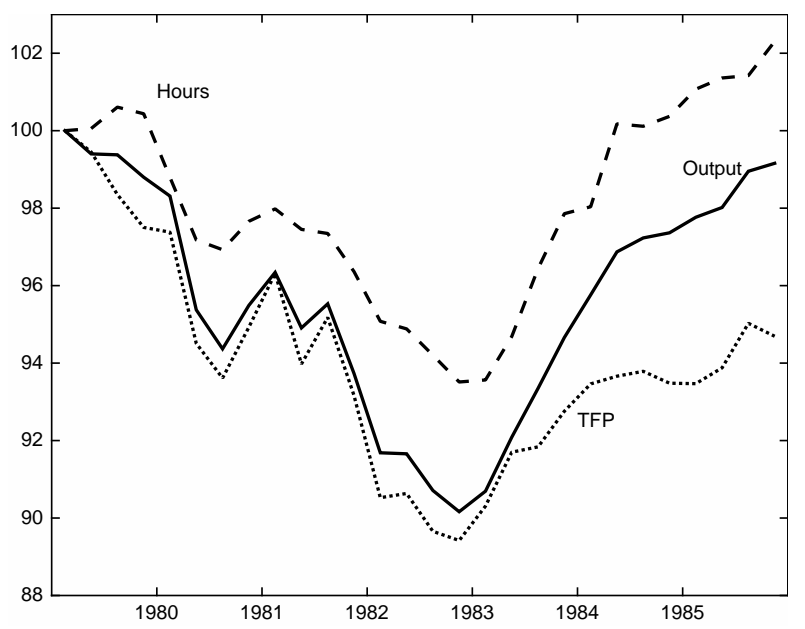

B. US Output and Hours in Great Recession

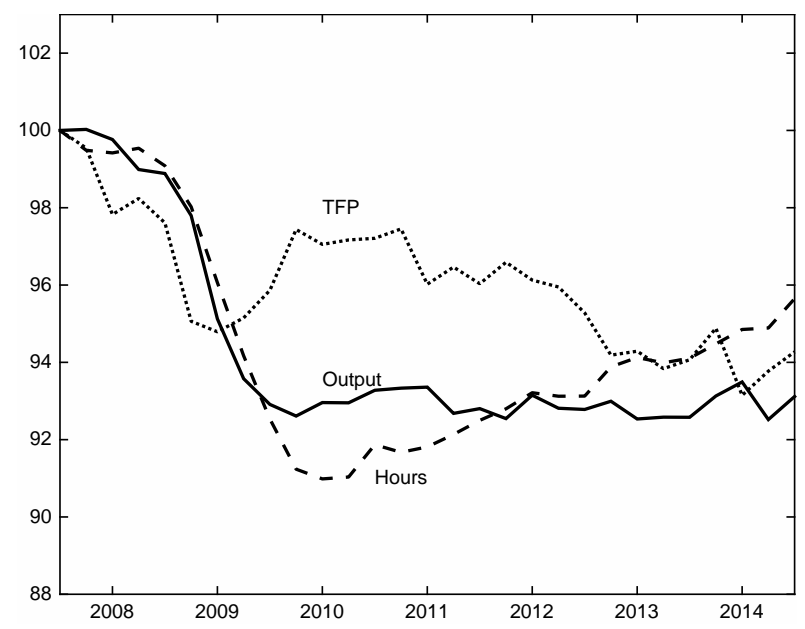


Figure 3: Great Recession Event (Arellano et al., forthcoming)

A. Interquartile Range of Sales Growth

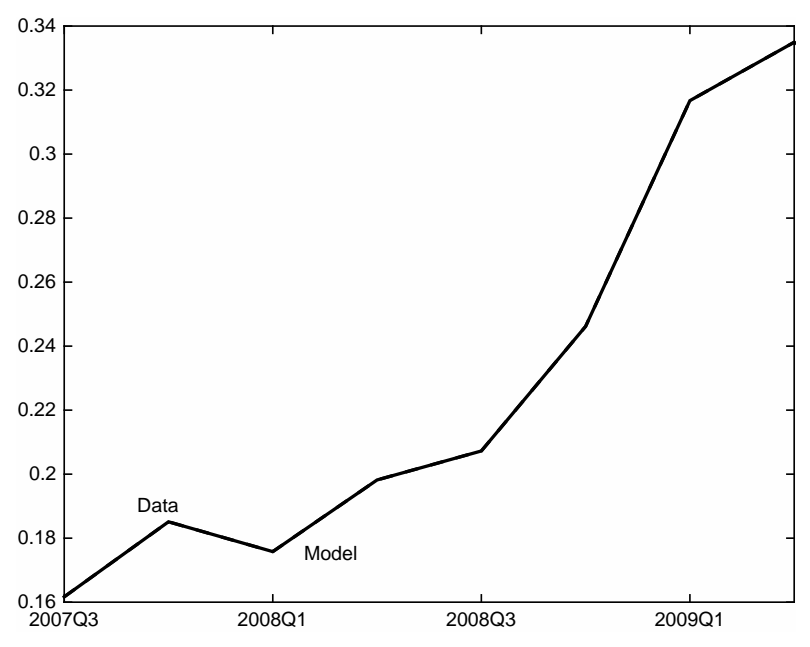

C. Labor

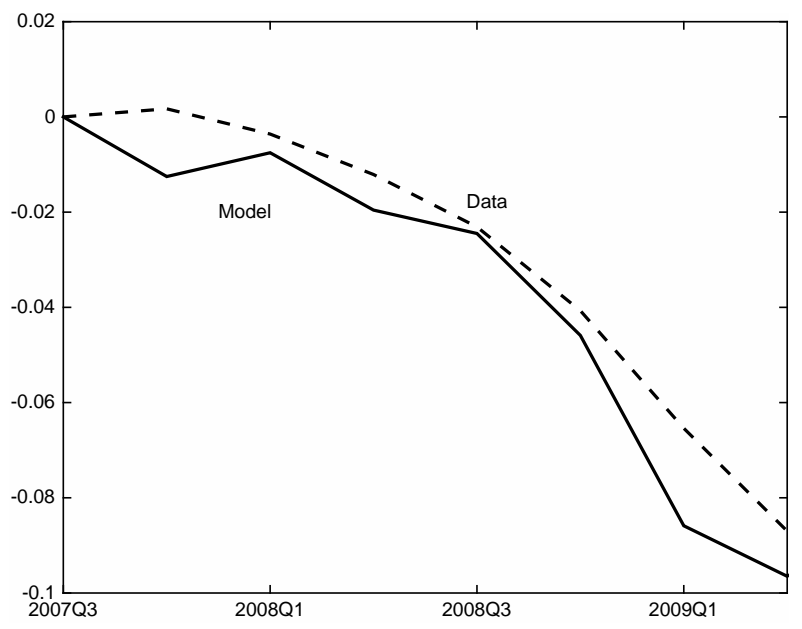

E. Debt Purchases

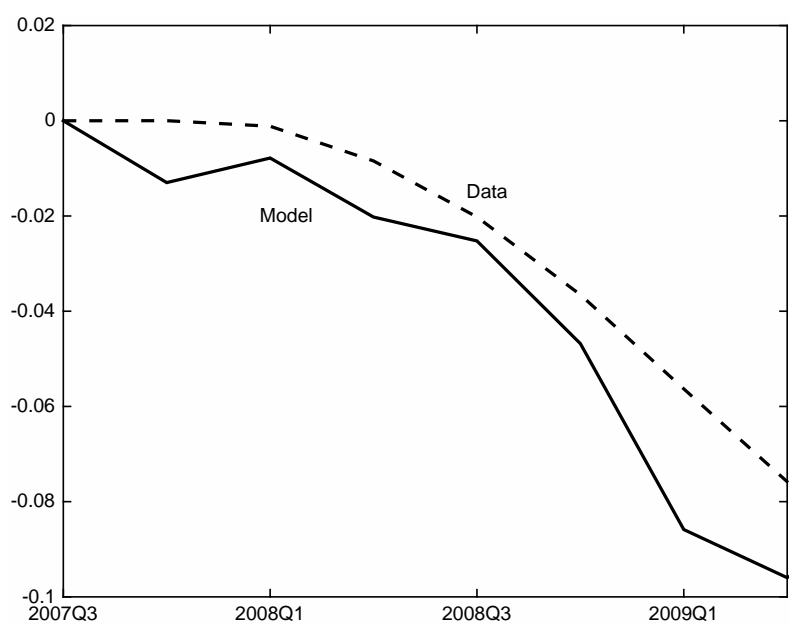

B. Output

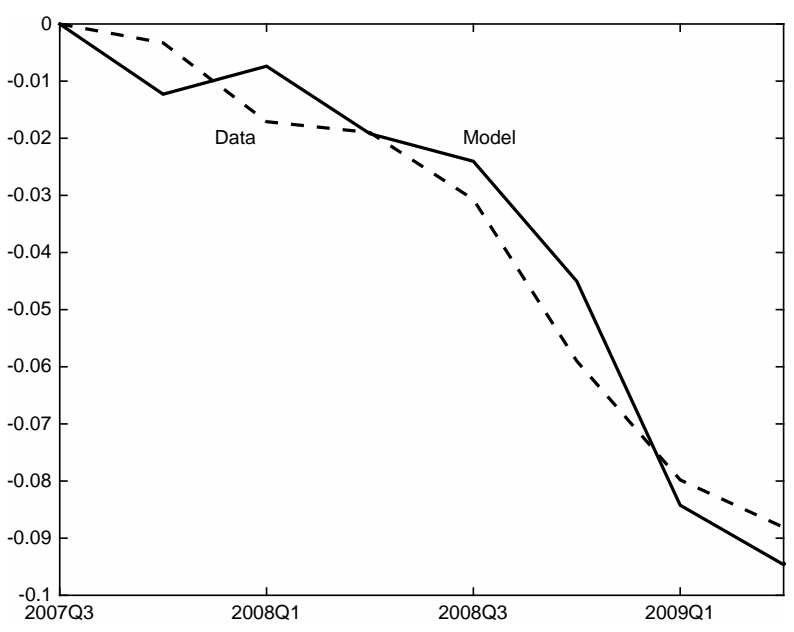

D. Credit Spreads

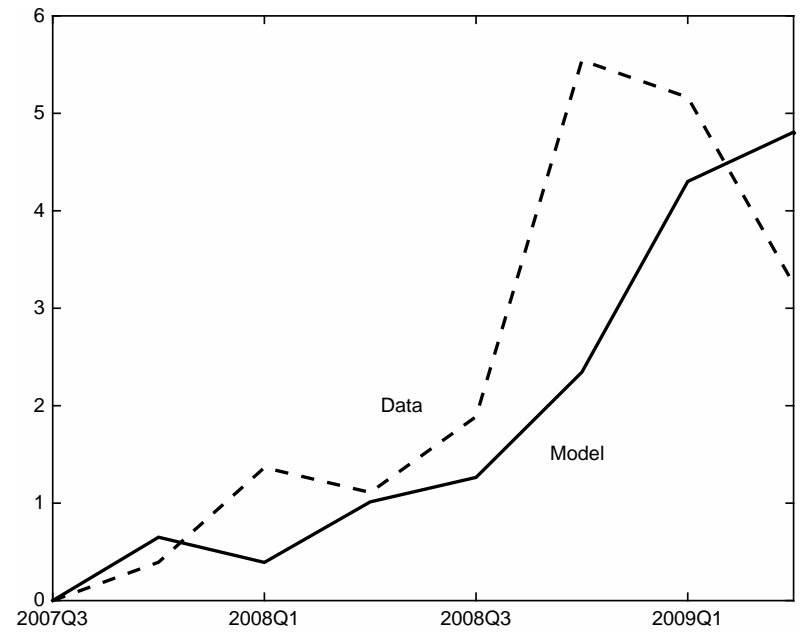

F. Equity Payouts

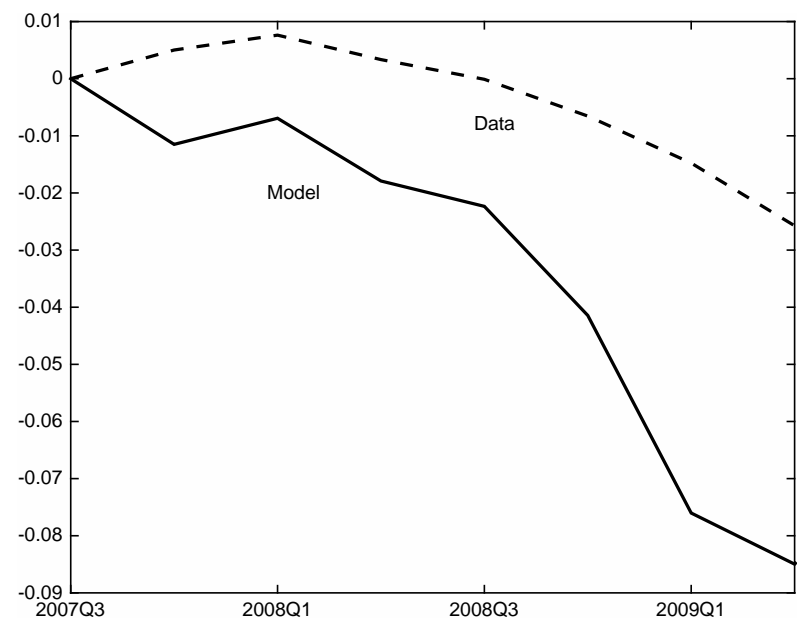




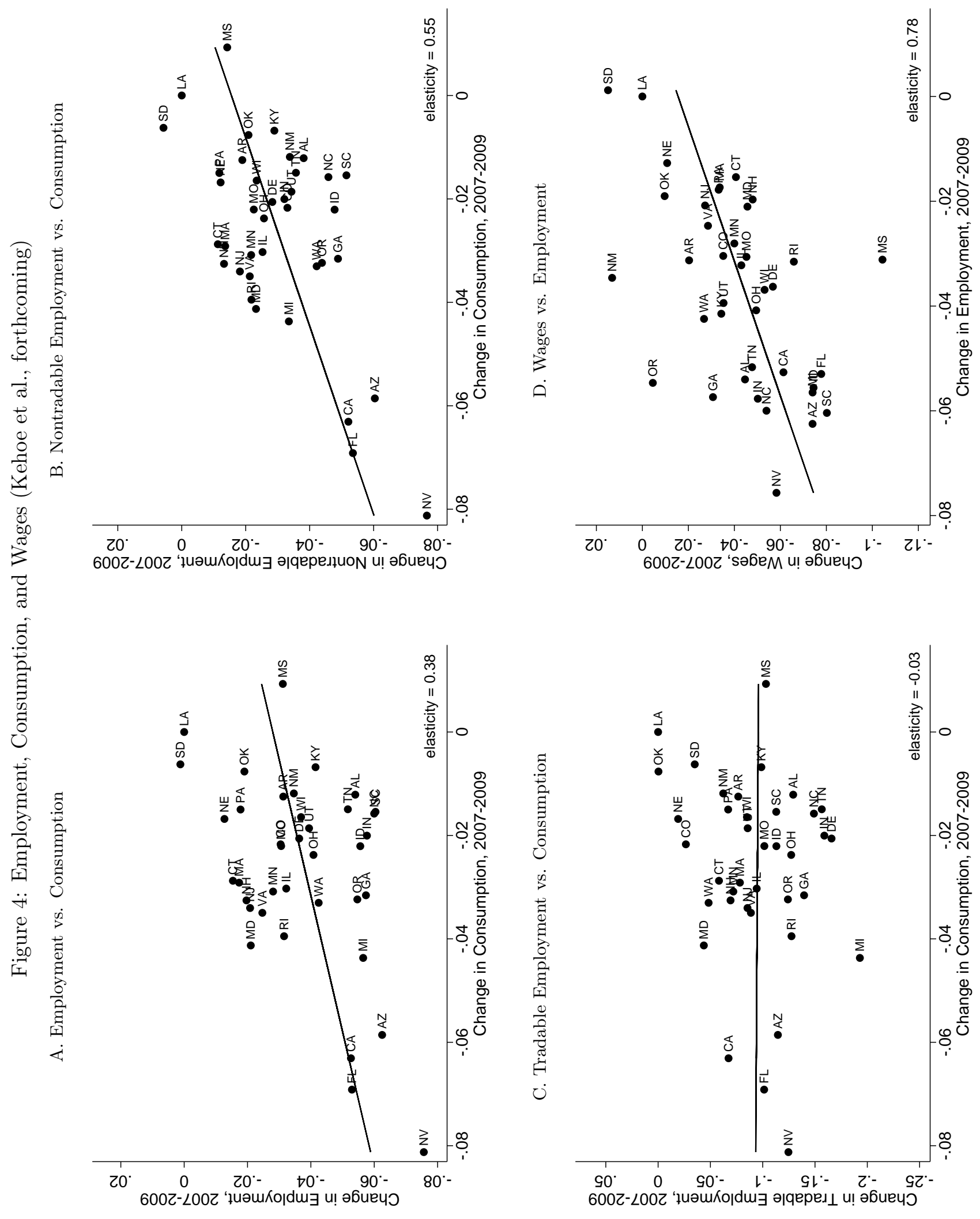

